\title{
Close-to-nature silviculture in eastern Quebec: Advances over the last decade
}

\author{
By Robert Schneider ${ }^{1 *}$, Laurie Dupont-Leduc ${ }^{1}$, Vincent Gauthray-Guyénet ${ }^{1,2}$, Nicolas Cattaneo $^{1}$, \\ Lara Melo $^{1}$, Tommy Simard ${ }^{1}$, Alexis Begni' ${ }^{1}$, Raphael Turquin ${ }^{1}$, Annabelle Morache-Mercier ${ }^{1}$, Samuel Pinna ${ }^{3}$, \\ Ulysse Rémillard ${ }^{4}$ and Charles Nock ${ }^{5}$
}

\begin{abstract}
The increase in intensity of the harvesting of eastern Quebec's forests has resulted in profound compositional changes at the stand level. The composition and structure of presettlement stands provide key benchmarks when implementing ecosystem-based management (EBM). A core principle of EBM is the emulation of natural disturbances, and it is hypothesized that forest resilience will be maintained. Managers have thus adapted some of their silvicultural activities to better mimic the main natural disturbances in eastern Quebec. These adaptations include using variable retention harvesting systems instead of clear-cuts and converting even-aged stands. Nevertheless, other close-to-nature silvicultural practices must be developed, as gaps between managed and unmanaged stands persist. Most importantly, there is a need to consider global change within EBM, which could be accomplished by prioritizing forest functions rather than composition or structure when establishing silvicultural objectives. Elements of the complex adaptive systems approach to increasing forest resilience can be incorporated into the larger-scale EBM approach. This could be done by considering the functional complementarity of species, forest function, and stand structure in forest management planning. These efforts must not be constrained, however, to allowable annual cut calculations, as these are not sufficiently sensitive to compare different management scenarios.
\end{abstract}

Keywords: ecosystem-based forest management, natural disturbances, long-term changes in forest composition, variable retention harvesting, conversion to multi-aged stands

\section{RÉSUMÉ}

L'intensification de l'aménagement des forêts de l'Est du Québec s'est traduite par une profonde modification de la composition forestière à l'échelle du peuplement. La composition et la structure des forêts préindustrielles nous fournissent des repères importants pour la mise en œuvre de l'aménagement écosystémique (ecosystem-based management EMB). En s'inspirant des perturbations naturelles pour guider les choix d'aménagement, l'EMB devrait maintenir la résilience des forêts. Les gestionnaires ont donc adapté certaines pratiques sylvicoles afin de mieux imiter l'effet des principales perturbations naturelles dans l'Est du Québec. On utilise notamment les systèmes de coupe à rétention variable comme substitut à la coupe avec protection de la régénération et des sols ainsi que la conversion des peuplements équiennes. Il importe toutefois de mettre au point d'autres techniques sylvicoles pour parer au fait qu'il existe toujours un écart entre les peuplements aménagés et ceux qui ne le sont pas. Mais il faut aussi tenir compte des changements climatiques dans la mise en œuvre de l'EMB, ce qu'on pourrait faire en misant sur les fonctions de la forêt plutôt que sur leur composition ou leur structure dans l'élaboration des objectifs sylvicoles. On peut ainsi inclure dans l'EMB des éléments des systèmes complexes adaptatifs pour accroître la résilience de la forêt. Cette approche devrait tenir compte de la complémentarité fonctionnelle des espèces, de la fonction des forêts et de la structure du peuplement dans la planification forestière. Cependant, ces efforts ne doivent pas être limités par les calculs de la possibilité forestière, qui n'offrent pas la sensibilité nécessaire pour comparer différents scénarios d'aménagement.

Mots-clés: aménagement forestier écosystémique, perturbations naturelles, changements à long terme de la composition forestière, coupe avec rétention variable, conversion vers des peuplements inéquiennes/étagés

\footnotetext{
${ }^{1}$ Université du Québec à Rimouski, Département de biologie, chimie et géographie, Rimouski, Qc G5L 3A1 ${ }^{\star}$ corresponding author: robert_schneider@uqar.ca

${ }^{2}$ Centre d'enseignement et de recherche en foresterie de Sainte-Foy inc. (CERFO), Québec, Qc, G5L 3A1

${ }^{3}$ Aristoloche, Gaspé, Qc, G4X 2Y6

${ }^{4}$ Conseil de la Premièr Nation des Innus Essipit, Essipit, Qc, G0T 1K0

${ }^{5}$ Faculty of Agriculture, Life \& Environmental Sciences, Renewable Resources Dept., University of Alberta, Edmonton, Alberta,

T6G 2R3
} 


\section{Introduction}

Harvesting activities in the province of Quebec date to when the province was under British control during Napoleon's continental blockade. Between 1808 and 1812, this blockade forced the British to find new sources of wood for naval construction. Licences were thus given to permit the harvest of large pine (Pinus spp.) and oak (Quercus spp.) trees, with few to no legal obligations regarding regeneration or silviculture (Blais and Boucher 2008). Harvesting for industrial purposes then began in the mid-1800s because of the increased demand for newspaper in the United States. This demand shifted forest tenures from licences to concessions, a period that lasted from 1849 to 1987 (Chiasson and Leclerc 2013). Legal obligations nonetheless evolved during the years of this tenure, with the main changes related to harvest sustainability. In eastern Quebec, harvesting began under the concessions tenure (Boucher et al. 2006). Harvesting occurred mainly in winter, and logs were then transported along waterways to the mills during the spring freshet. The concessionaires were responsible for all forest management operations, including inventory. The cutand-run harvesting relied mainly on diameter-limit cutting in primary forests. Diameter limit is driven by economics (trees smaller than a certain threshold were not harvested) with little regard to the future stand (Nyland 2002). Despite this, the diameter-limit harvested stand can evolve toward a structure resembling that of the preharvest stand, although its composition is often altered (Fortin et al. 2003). More often than not, however, diameter-limit cutting is associated with high grading (Raymond et al. 2020).

In the 1970s, harvesting operations became increasingly mechanized, making it possible to harvest larger cutblocks at greater distances from the rivers and lakes originally used for log transport (Boucher et al. 2009a). Societal pressures to grant access to the public forests of the province caused the Quebec government to change the forest tenures in 1987 (Blais and Boucher 2008); companies secured 25-year procurement contracts, which guaranteed a stable volume of supply to their mills. In return, companies were required to follow guidelines set by the Quebec Ministry of Natural Resources. Management plans were built around allowable annual cut (AAC) calculations that set the harvesting levels. Silvicultural interventions were thus bound by the effect they had on the AAC.

This most recent change in forest tenure was also accompanied by an increased interest in silviculture. Forest management pertains to decisions that shape forests at the landscape level (Raulier et al. 2009) by dictating when, where, and how interventions are carried out. Silviculture, on the other hand, proposes a sequence of interventions for a given forest stand to reach specific objectives, such as stand composition, regeneration targets, and/or timber products. Thus, decisions involving cutblocks, in terms of their location, size, and number, and the frequency of harvesting activities fall within the realm of forest management decisions. Silviculture is one of the tools used by managers to attain their objectives.

A shift in the 1980s placed the responsibility for forest management under the control of the Quebec government and resulted in an increased emphasis on silvicultural scenarios based on stand composition. In most softwood stands and stands with shade-intolerant deciduous species, such as trem- bling aspen (Populus tremuloides Michx.), even-aged harvesting systems are used. This includes clear-cutting while protecting established regeneration, followed by planting, if needed, then brushing and/or pre-commercial thinning, and commercial thinning. Stands dominated by shade-tolerant hardwoods, such as sugar maple (Acer saccharum Marshall), or those having a high proportion of northern white-cedar are treated as uneven-aged stands having either individualtree or grouped-selection harvesting (Guillemette et al. 2013). Stands-regardless of composition-are classified as either even-aged, i.e., a stand composed of trees that belong to the same 20-year age class, or uneven-aged, i.e., a stand composed of trees with at least three 20-year age classes (Raymond and Bédard 2017). This classification depends on 1) the predominance of tolerant/intolerant species and 2) negotiations between industrial stakeholders and forest managers and the relevant applied scenario, i.e., either even-aged or uneven-aged.

The management practices of the last century have had profound impacts on the current composition and structure of the forests (Danneyrolles et al. 2019). The differences between managed and unmanaged forests have pushed the Quebec government to adopt ecosystem-based management (EBM) as the driver of management decisions aimed to minimize these differences. This paper draws a portrait of the legacies confronting modern silviculturists within the framework of EBM. An overview is provided of the most important natural disturbances to identify the processes that must be integrated into close-to-nature silvicultural practices. Current ecosystem-based practices and decisions based on management decision tools such as the AAC are then examined. Finally, perspectives are proposed and challenges facing ecosystem-based management over the coming next decades are discussed.

\section{Foundations of ecosystem-based forest management (EMB): past versus present-day forests in eastern Quebec}

Forest surveys of the late 1800s and early 1900s offer a portrait of the composition and structure of unmanaged forests in Quebec (Danneyrolles et al. 2019). The preindustrial forests of eastern Canada comprised coniferous mixedwoods; most of these forests were irregular, i.e., stands marked by a large variability in tree height, or old-growth forests (Etheridge et al. 2005; Dupuis et al. 2011). The comparison of concession surveys with the decennial forest inventories carried out by the provincial government since the mid-1970s reveals shifts in the composition and structure of these forests (Boucher et al. 2006). Over the last century, the abundance of broadleaved species, including trembling aspen, white birch, and sugar and red maple (Acer rubrum L.), has increased relative to that of conifers such as white spruce and northern white-cedar (Boucher et al. 2006, 2009b; Dupuis et al. 2011; Danneyrolles et al. 2017). The increase in deciduous species at the expense of conifers over several decades has led to higher nutrient availability in the upper soil layer (GauthrayGuyénet et al. 2018). A greater radial increment in balsam fir has been observed on sites characterized by higher concentrations of nitrogen (Gauthray-Guyénet et al. In press), highlighting this indirect effect of shifts in stand composition on tree growth. 
Present-day landscapes in eastern Quebec are comparatively more fragmented than in the past, owing to both access roads and the use of mosaic harvesting patterns and other forest management decisions. The few remaining old-growth forests are not continuous; thus, old-growth-associated plant and animal populations are isolated from each other (Groupe d'experts sur la sylviculture intensive de plantations 2013). A consequent decrease in forest biodiversity has thus been observed (Etheridge et al. 2006; Aubin et al. 2008; Barrette et al. 2014).

The forested landscapes in eastern Quebec are also characterized by large areas now covered by plantations. The high proportion of plantations is explained by the major spruce budworm (SBW; Choristoneura fumiferana Clem.) outbreak in the 1980s (Boulanger and Arseneault 2004). Extensive salvage cutting to harvest dead trees, combined with the Quebec government's plan to plant 300 million seedlings per year, markedly increased the proportion of plantations (Boucher $e t$ al. 2006). The silvicultural and forest management heritage, coupled with the pressure from the public and some environmental groups, encouraged the government to propose new sustainable forest management legislation which brought EBM practices to the fore (Gouvernement du Québec 2015). To reach EBM objectives, management decisions and silvicultural approaches must better emulate the variations in intensity, frequency, and size of natural disturbances within forests (Gauthier and Vaillancourt 2008).

The gap dynamics of eastern Quebec forests are driven by minor disturbances, including snowfall, freezing rain, and windthrow. Nevertheless, SBW is the major driver and has a cycle of approximately 40 years between outbreaks (Boulanger and Arseneault 2004). SBW larvae feed on balsam fir and spruce buds, and tree mortality can occur after four to five years of heavy defoliation (MacLean 1980; MacKinnon and MacLean 2004; Bouchard and Pothier 2010). Outbreak severity and its spatial distribution vary between events (Martin et al. 2019). Such moderate disturbances drive the processes that produced the heterogeneous old-growth stands observed in presettlement forests (Kneeshaw and Bergeron 1998; De Grandpré et al. 2011).

Silviculturists thus face a clear and significant challenge. They must propose methods to: (i) increase compositional diversity; (ii) guide stands toward an uneven-aged structure or, at the very least, increase key uneven-aged attributes in managed stands; and, (iii) increase stand structural complexity. The following sections will explore how to achieve these objectives.

\section{Close-to-nature silviculture, including natural forest characteris- tics within managed stands}

Ecosystem-based management (EBM) sets the objectives for a management unit, whereas silviculture proposes systems to reach stand-level goals. Post-harvest stands present an altered stand structure, including changes in tree species composition and the suppression or limitation of certain stages of ecological succession, e.g., large mature trees, and structuring elements of the ecosystem, e.g., coarse woody debris and snags (Hansen et al. 1991; Bergès et al. 2002). Managed stands thus differ greatly from natural stands (Harvey et al. 2002). Moreover, silvicultural interventions are now the most widespread disturbances in eastern Quebec forests, if not the most important. Since 2014, EBM has been a legal obligation in Quebec and any management plan must involve silvicultural treatments that aim to maintain or restore natural ecosystem properties-composition, structure, and function-within stands and across the landscape. Close-tonature silvicultural approaches, which emulate natural disturbances, should focus on maintaining the critical ecosystem processes and landscape patterns (Bergeron and Harvey 1997). Although the fundamentals of close-to-nature silviculture are widely accepted, implementing these concepts remains a challenge.

The different characteristics of natural disturbances, e.g., frequency, scale, and severity, must be taken into account in silvicultural guidelines because variations in these parameters modulate the effects of a disturbance at both the stand and landscape levels (Bergeron et al. 1999; Lorimer and White 2003; De Grandpré et al. 2018). An EBM approach has been proposed for eastern Quebec (Kneeshaw et al. 2008). It holds that, on average, $39 \%$ of a management unit should be under an even-aged silvicultural scenario, whereas the remaining portion of the unit should be under an uneven-aged scenario characterized by varying intensities of canopy removal. The current operational management plans, having up to $90 \%$ of the silvicultural scenarios represented by even-aged stands, differ greatly (by approximately $50 \%$ ) from the levels suggested by the variations among historical disturbances (Gagnon et al. 2018).

The high proportion of even-aged systems reflects the fact that most stands in eastern Quebec have been harvested at least once using a clear-cut approach over the last century. Converting areas of managed forests into irregular or uneven-aged structures (and toward a more natural range of variability) takes decades and requires a series of silvicultural interventions (Schütz 1997, 2001, 2002; O’Hara 2002; Nyland 2003; Franklin et al. 2007). As well, there is a temporal window when it is optimal to start the conversion process and minimize the time required to achieve the desired structure. The greater the age difference between the dominant cover and regeneration, the longer the dominant cover must be maintained to create an irregular stand, thereby lengthening the conversion process (Schütz 1997). In eastern Quebec, the ideal moment to begin conversion is when the stand is ready for a first commercial thinning; that is, when the stand is at the pole/sapling stage dominated by trees generally less than 40 years old. The conversion involves maintaining trees from the original cohort and promoting regeneration in the understorey (Thomas et al. 1979; Schütz 1997; Nyland 2003). The conversion process comprises four steps (Schütz 2001): (1) stand differentiation (establishing different crown classes); (2) regeneration promotion of long-lived species (created by thinning or gaps); (3) structural development (establishment of the first regeneration cohort); and, (4) consolidation of the uneven-aged structure (silvicultural interventions to maintain an uneven-aged structure).

Commercial thinning by crop tree release has been tested as a means of initiating this structural conversion in white spruce plantations (Gagné et al. 2016, 2019). This approach has also been recommended for use in other forest types as a strategy for accelerating old-forest development (Singer and 
Lorimer 1997). This silvicultural treatment targets highgrowth-potential stems (codominant or dominant trees, long-lived species, vigorous growth, regular form, absence of apparent defects) and releases these stems from their direct competitors (Bastien 2005; Grenon et al. 2007). This approach enhances the growth conditions of the crop trees (more light, less competition) and, at the time of harvest, results in a high-quality stem (a cylindrical trunk without decay or coloration) (Cameron 2002; Baar et al. 2004; Lundqvist et al. 2007). The released trees play a structuring role as they are intended to provide the framework of the developing irregular stand (De Potter et al. 2012). Thinning by crop tree release must be viewed as a first step toward structural conversion, and no final cuts of the stand are planned. Indeed, during each harvesting pass, the selected crop trees are protected from harvesting and will form the dominant cover over the next several decades through which recruited trees will grow. Continuously recruited crop trees will produce, over time, an irregular stand structure (Schütz 2001; O'Hara 2002). A limited number of trees could produce high- quality timber at each harvesting entry and contribute the most to the total financial return of each entry, at least in mixed stands (Lambert et al. 2007). This approach has yet to be used in softwood stands in eastern North America; it nonetheless represents an innovative approach and may provide an interesting pathway to mimic gap dynamics which are key processes in eastern Canadian forests. Several forest stakeholders remain resistant to this shift in silvicultural practices, as some forest managers have questioned the conversion process by crop tree release because of the possibility that such a thinning might reduce stand yield (Bédard et al. 2003; Laflèche et al. 2013).

To address these concerns, Dupont-Leduc et al. (2020) recently undertook a thinning trial in eastern Canada, applying two intensities of crop tree (CT) release $(50 \mathrm{CT} / \mathrm{ha}$ and $100 \mathrm{CT} / \mathrm{ha}$ ) and thinning from below (approx. $35 \%$ of stand basal area). An unthinned control was established in white spruce plantations and balsam fir-dominated, naturally regenerated stands (Dupont-Leduc et al. 2020). This trial aimed to compare the growth and structure of managed stands during the first step of the conversion process. Preliminary results indicated that, after five years, trees thinned by crop tree release showed a significantly higher diameter at breast height ( $\mathrm{dbh}$ ) increment than those in the control plots and produced greater dbh increments than their closest neighbours (Dupont-Leduc et al. 2020). At the stand level, crop tree release did not reduce stand growth, as there was no difference between the thinned-from-below and control stands (Dupont-Leduc et al. 2020). These findings should therefore address the concerns regarding reduced stand yield expressed by regional forest stakeholders. In terms of structure, although not statistically significant, a release of 100 $\mathrm{CT} /$ ha increased tree aggregation, whereas the authors observed no effects in regard to diameter distribution (Dupont-Leduc et al. 2020).

Simulation results over a 25 -year horizon confirmed that crop tree release can lead to more complex stands without hindering stand productivity (Schneider et al. 2021). In both studies, crop tree release represented the first step (stand differentiation) of the conversion process. Further interventions are nonetheless required to stimulate gap dynamics and con- tinue toward the final objective of structural conversion. Although crop tree release is being used operationally in $10 \%$ to $15 \%$ of the commercial thinning operations in eastern Quebec, the problem arises that conversion has typically targeted the lowest productivity plantations, i.e., stands marked by the lowest site indices. To generate complex stands varying in richness, however, the conversion process must be applied to sites across a range of site indices.

Conversion by crop tree release represents a pathway to increase, over a long time period, the proportion of unevenaged stands in the landscape. Kneeshaw et al. (2008) proposed that a quarter of the stands in eastern Quebec could undergo a high level of harvesting, i.e., more than $50 \%$ canopy removal. This proposal led to variable retention harvesting (VRH) being adopted in eastern Quebec as a means of conserving or generating more complex post-harvest stands. VRH was introduced in western North America in the mid-1990s to reconcile fibre production and habitat protection; it has since been exported to other forest biomes around the world, including the boreal forest (Mori and Kitagawa 2014; Gustafsson et al. 2020). The underlying idea of $\mathrm{VRH}$ is to mimic natural disturbances to conserve biological legacies and maintain/increase post-harvest stand complexity (Franklin et al. 1997). VRH achieves this by either leaving individual trees (dispersed retention), groups of trees (aggregated retention), or a mixture of both within a cutblock (Mitchell and Beese 2002). All variations of VRH structure the future stand by keeping large living trees across the regenerating stand. As these trees die, large coarse woody debris is produced. When groups of trees are preserved, these clusters act as lifeboats for those species not adapted to regenerating forests, species that could eventually recolonize the stand. Retention thus influences the development of the future stand by creating undisturbed patches and helps maintain certain processes observed in old-growth forests (Franklin et al. 2002).

In Quebec, VRH was first proposed to reduce structural differences between post-fire and post- harvest stands in the boreal forest by leaving legacies such as single trees and groups of live trees, which are often observed in fire-disturbed stands (Bergeron et al. 2002). When ecosystem-based forest management became a legal obligation in 2014 (Gouvernement du Quebec 2015), VRH became mandatory for clear-cut stands, with a recommended level of $25 \%$ retention and a minimum of $5 \%$ retention (Ministère des Forêts, de la Faune et des Parcs 2017a). This EBM obligation was province-wide, irrespective of forest type. In eastern Quebec, forest managers opted to retain $5 \%$ of the cutblocks through the aggregated retention of $200-300 \mathrm{~m}^{2}$.

The effectiveness of VRH in the region's forests remains to this day debated among practitioners. If most trees fall down within the first five years after stand harvesting, as has been confirmed by field observations, the objectives of the aggregate VRH are not met; the longer-term biological legacy and the production of large-sized coarse woody debris fail to occur.

In 2007, a VRH experiment began in the Gaspésie region (Pretzsch et al. 2014). Twenty-four permanent sample plots $\left(40 \mathrm{~m}^{2}\right)$ were established before harvesting within the retention groups (Fig. 1) of three stands composed of balsam fir, black spruce, and white birch. 


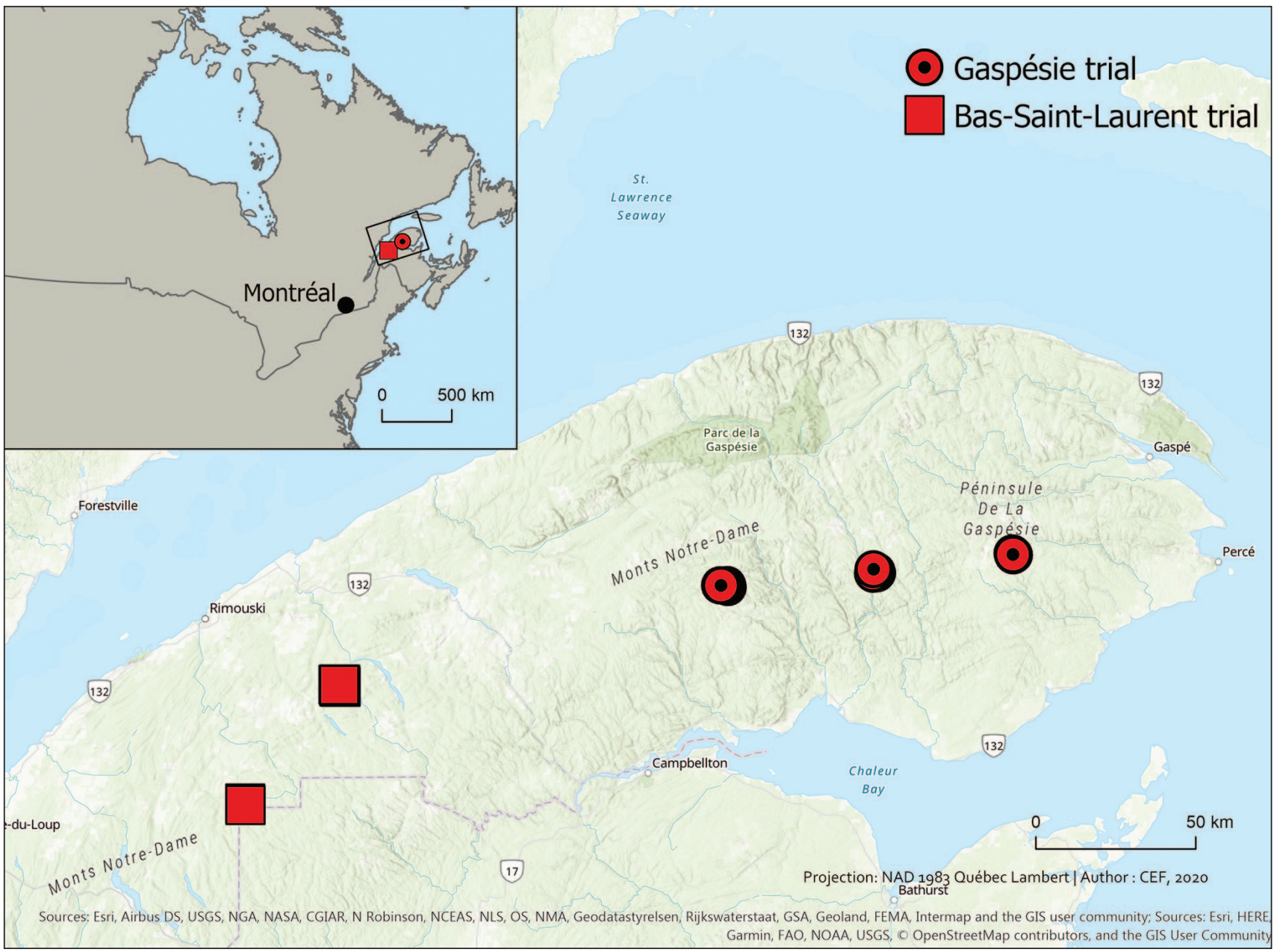

Fig. 1 Study site locations for the variable retention harvesting trials

The dbh of trees within the plots were measured immediately before and after harvest and then again five years post-harvest. The change in basal area over five years, i.e., $\left(\mathrm{BA}_{2012}-\mathrm{BA}_{2007}\right) / \mathrm{BA}_{2007}$, related strongly to the retention groups wind exposure and retention group composition (Fig. 2). Retention groups having lower topographical exposure (TOPEX) values experienced greater losses-TOPEX measures wind exposure (Ruel et al. 2002), and the lowest values are associated with more wind-exposed sites near the topographic highs. Group composition diversity, quantified using the basal area-derived Shannon index (Shannon 1948), showed that more diverse groups (higher index values) exhibited less windthrow loss. Finally, group size and basal area loss showed a slight positive relationship as larger groups experienced slightly less windthrow damage. Variable-radius plots having a two-factor prism from the same retention groups produced similar results and are thus not presented. A similar study in the Bas-Saint-Laurent region of eastern Quebec (Rémillard and Schneider 2015), approximately 300 $\mathrm{km}$ southwest of the abovementioned experiment (Fig. 2), followed 12 retention groups within three sites. The sites were followed for three years after harvesting (2011-2013). Annually, all trees within the retention groups had their $\mathrm{dbh}$ recorded. A terrestrial laser scanned each retention group from five to nine positions, and the resulting $3 \mathrm{D}$ point clouds allowed the production of a digital canopy map and digital terrain map. The digital height model (DHM) was then obtained by subtracting the digital canopy model from the digital terrain model. The DHM was then classified into four height classes (Fig. 3), which served to extract a number of metrics describing the canopy shape of the retention blocks. These metrics included canopy density (horizontal projection area per height class), mean patch area and number of patches per height class, the connectivity of each class, and the division index (DIVI) of each class. As well, the rumple index (ratio of the area of the DHM to the projected area) quantified heterogeneity. The change in height structure over the three years varied among the retention groups (Fig. 3), with some groups having high windthrow losses and others none. The smaller retention groups experienced a relatively greater loss because of windthrow (Fig. 3). The structural diversity of the retention group at the time of harvest, measured by the rumple index, minimally affected windthrow loss (Fig. 3). Retention groups having a high canopy density of the tallest trees at time of harvesting showed greater windthrow damage after three years.

Although these trials had few replicates, they are the only studies in the area tracking how retention groups survive 

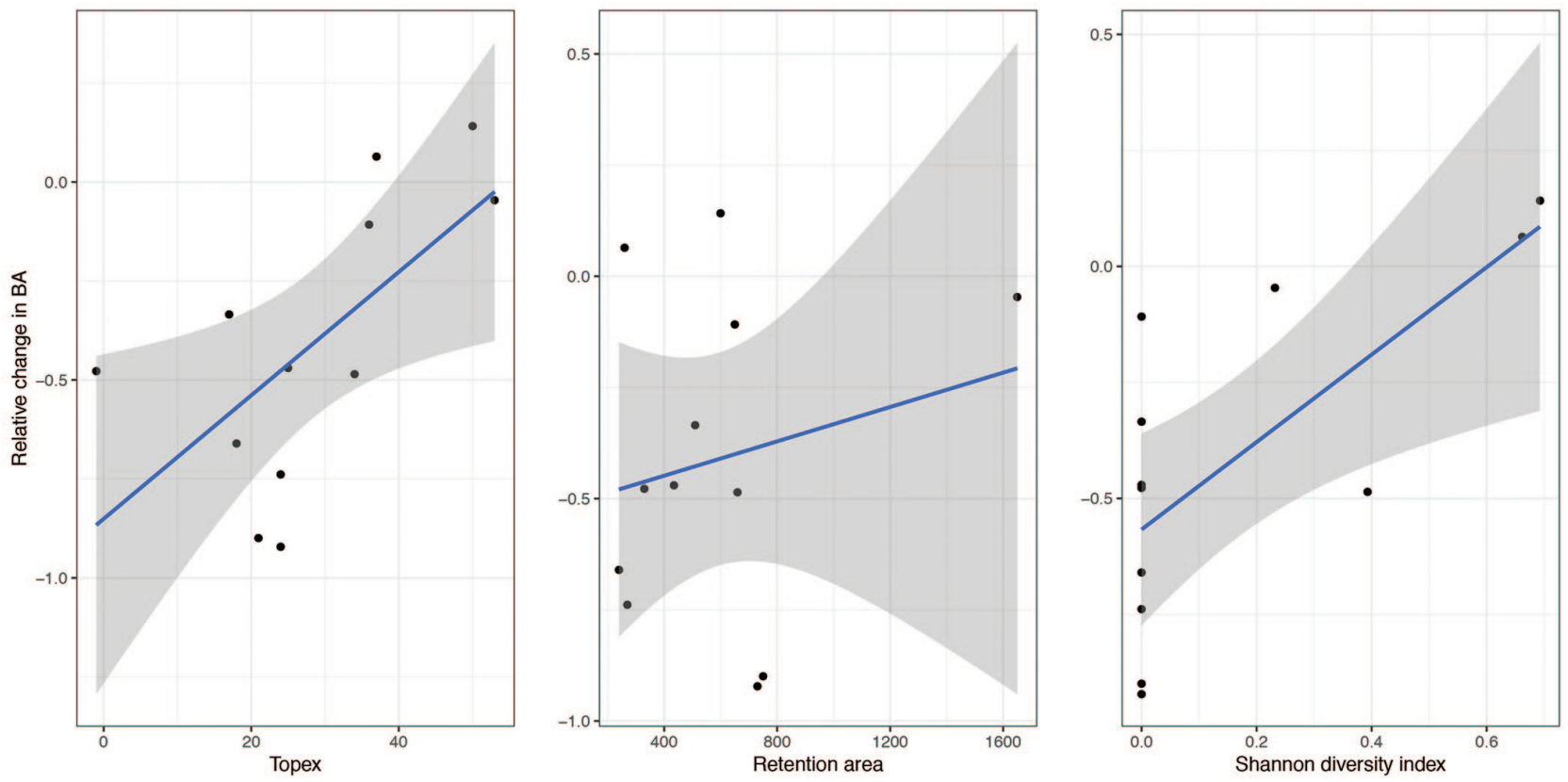

Fig. 2 Relationship between changes in basal area as a function of TOPEX, retention group area, and Shannon diversity index for the Gaspésie trial

post-harvesting. More importantly, these trials highlighted what practitioners were observing in the field: smaller retention groups, i.e., $<1000 \mathrm{~m}^{2}$, experienced greater windthrow within the first few years post-harvest, and the more diverse groups appeared to persist longer. The objectives of conserving longer-term biological legacies and the production of large-sized coarse woody debris were thus not attained using small retention groups. Their size was thus increased from $200-300 \mathrm{~m}^{2}$ to $2000 \mathrm{~m}^{2}$. Moreover, they are used in $20 \%$ of the clear-cuts, in stands where long-lived species are present.

The conversion process applies to landscapes that lack uneven-aged stands. Although a promising approach owing to the retention of large groups, VRH cannot, by itself, help attain the recommended partitioning of even-aged to uneven-aged pathways. Other silvicultural approaches must be explored, such as expanding-gap silvicultural systems, which have been tested within similar forest types in Maine, USA (Seymour et al. 2006; Carter et al. 2017). The principle is to create gaps-either small to favour shade- tolerant regeneration or large to encourage intermediate shade-tolerant species-which are then expanded at each cutting cycle. Moreover, all trees in the gaps can be felled. Alternatively, reserve or temporary upper canopy trees can be kept standing. Reserve trees are left after every cutting cycle to promote regeneration, whereas upper canopy trees are kept to control light conditions and minimize the regeneration of shadeintolerant species. These canopy trees can eventually be harvested during one of the subsequent entries. In the initial trials, very little reserve-tree mortality was observed (Carter et al. 2017).

Although shelterwood and VRH are presently being used in combination within even-aged to uneven-aged conversions, there is a need to develop and integrate other practices to increase structural and compositional diversity within a given stand. Expanding-gap systems offer this possibility as they can be easily adapted to eastern Quebec's forests and increase the diversity of potential scenarios for a given stand. In turn, this diversity in silvicultural scenarios will lead to greater heterogeneity across the landscape.

Management considerations and constraints when using annual allowable cut calculations

Although close-to-nature silviculture is the focus of this paper, we must also consider certain limitations related to management decisions. In Quebec, foresters initially establish management objectives on the basis of land base characteristics, e.g., age structure and composition, in concertation with various stakeholders. The annual allowable cut volumes (AAC) are then calculated to assess the forest capital and guide management activities. The AAC is the cornerstone of every management decision. Included within the AAC are the objectives of increased economic profitability and greater wildlife habitat conservation. The AAC is established by maximizing the amount of volume that can be harvested in a management unit such that the annual harvest levels remain constant. It is evaluated over a 150-year horizon and is recalculated every five years. AAC estimates rely on growth curves generated by stand- and tree-level growth and yield simulators (Fortin and Langevin 2010; Pothier and Auger 2011); both simulators can produce growth curves and the associated uncertainties.

Dealing with uncertainties in AAC remains challenging despite their great effect on management decisions. Uncertainties arise from different sources, including model and sampling errors (Kangas and Kangas 2004). Model uncertainty is related to, among other aspects, parameter estima- 


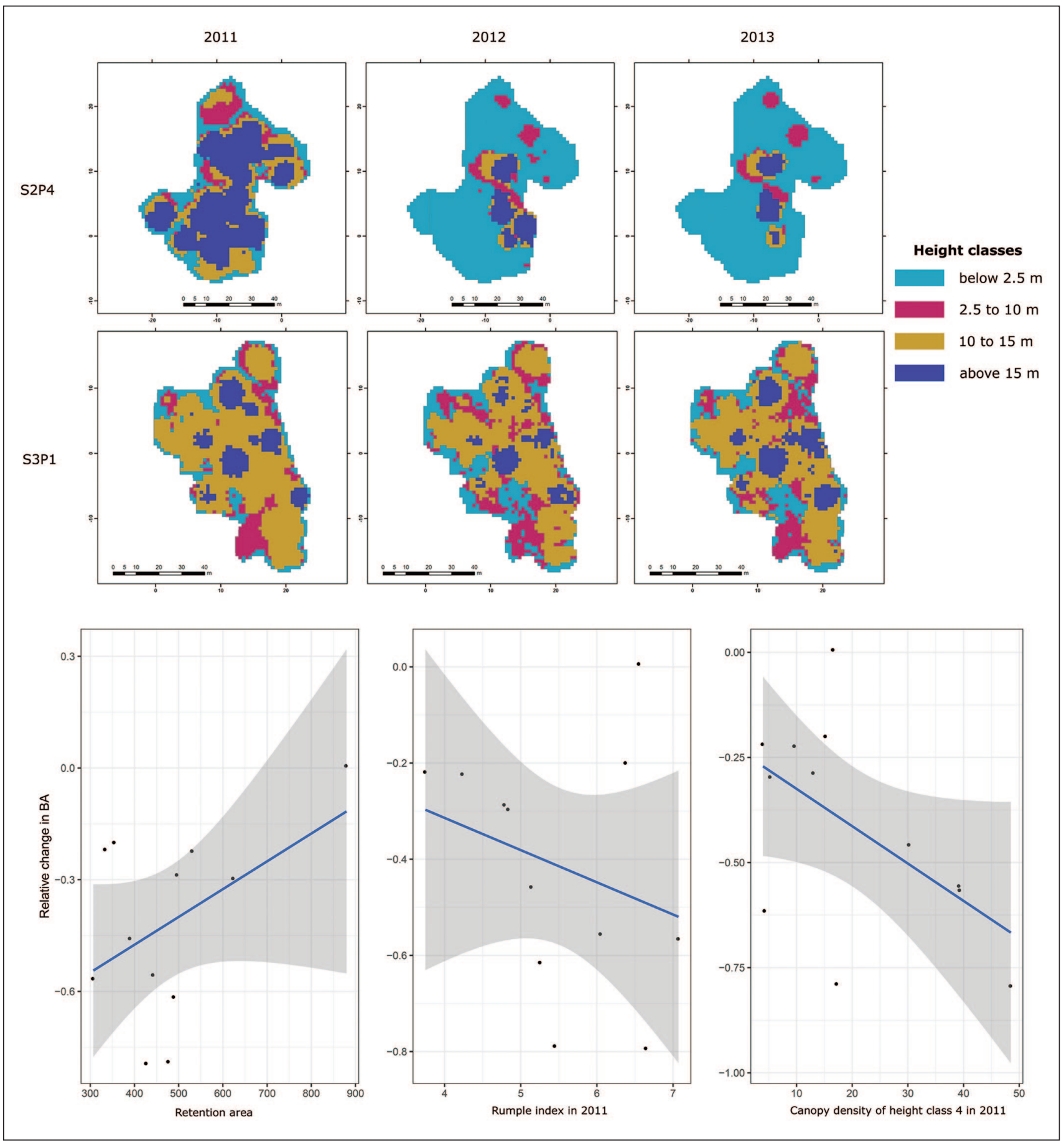

Fig. 3 Illustration of the change in retention group height classes for two groups (top) and the relationship between changes in basal area as a function of retention group area, rumple index, and canopy density of height class 4 (bottom)

tion, residual errors, and the concept and structure of the simulator (Walker et al. 2003). Sampling uncertainty represents the error that comes from making inferences when only a portion of the population is known (Condés and McRoberts 2017). In other words, the parameters of the entire population are unknown.

While the growing interest in the sources and estimates of uncertainties has been the subject of several studies in forestry (e.g., Ståhl et al. 2010; Corona et al. 2014; McRoberts et al. 2016), these efforts have yet to be incorporated into management activities. In Quebec, AAC calculations are presented with their uncertainties. The uncertainties are addressed, among others, by a sensitivity analysis, conservative assumptions, and the five-year review of the AAC calculations (Rheault 2013). Furthermore, risk analysis is only required when there is a high probability that an event such 
as a SBW outbreak may occur after an AAC determination. The upward or downward effects of the various uncertainties are not mentioned in the 2018-2023 AAC calculations, and the estimated prediction errors of the forest growth models used in the calculations are limited to a modelling horizon of approximately 40 years.

Melo et al. (2018) recently reported an error propagation assessment based on 100-year growth predictions in the administrative region of the Bas-Saint-Laurent in eastern Quebec. In the first step of this assessment, the authors indicated that the contribution of the model- and the samplingrelated errors to the total uncertainty of growth predictions depended on the time horizon and the spatial scale. Sampling error was the most important source of uncertainty in shortterm predictions, i.e., in the first 50 years, in growth predictions for eastern Quebec. In long-term predictions (after 100 years), the model contribution to error was as important as that of sampling error. From this trend, for larger areas in which the sampling size is greater, the model error could become the main source of uncertainty even for mid-term predictions, e.g., 50 years. Melo et al. (2018) also decomposed the total model error, finding that the mortality submodel increased the variance of the predictions from $35 \%$ to $60 \%$.

Melo et al. (2019), in the second step of their assessment of the Bas-Saint-Laurent region, included the effect of disturbance on the uncertainty of growth predictions. The authors estimated the contributions of SBW and harvesting and then compared these contributions to uncertainty with that arising from sampling error. The scenarios accounting for SBW outbreaks increased total uncertainty by $80 \%$ after the initial 30 years of the 100-year simulation horizon. Efforts to increase sampling size and develop efficient sampling designs decrease overall uncertainty, although according to Melo et al. (2019), priority should be given to predicting the occurrence of natural disturbances. The authors propose a perspective of these uncertainties (Fig. 4) in which a 100-year volume prediction is produced for different scenarios, including a more realistic scenario involving simultaneous harvesting and SBW outbreaks. When these disturbances occur simultaneously, the average volume is predicted at around 190 $\mathrm{m}^{3} \cdot \mathrm{ha}^{-1}$ at the end of the simulation, with confidence intervals of around $\pm 30 \mathrm{~m}^{3} \cdot \mathrm{ha}^{-1}$. It is reasonable to infer that a 150 -year growth prediction would have an even larger confidence interval.

By drawing from the aforementioned results and applying forest growth models to produce 150- year growth predictions, we can assume that model errors represent the greatest source of uncertainty. In practical terms, these model errors might induce an unachievable amount of growth where managers may come to find a 'serial uncertainty.' To demonstrate this argument, let us consider an example of management decisions based on the AAC calculations in eastern Quebec. In the Bas-Saint-Laurent region, around 1.4 million $\mathrm{m}^{3} \cdot \mathrm{ha}^{-1}$ per year (between 2018 and 2023) have been made available for harvesting (Ministère des Forêts, de la Faune et des Parcs 2018). This region has been affected by a SBW outbreak since 2013, and outbreaks normally last about ten years. In 2016, almost $50 \%$ of the total area was defoliated by SBW (Ministère des Forêts, de la Faune et des Parcs 2017b). Models used in the AAC calculations consider the occurrence of SBW outbreaks; however, the error propagation is not accounted for when working with large areas and long-term predictions. Hence, the amount of timber to be harvested in forest planning is most certainly sensitive to errors arising from the modelling assumptions.

Another caveat related to the AAC in Quebec is that it is used as a baseline to evaluate the effect of various silvicultural scenarios. When new silvicultural interventions are proposed, managers request that the impact of these interventions on AAC be evaluated. If they note a drop in AAC, the new intervention is generally discarded, even when the ecological foundations are sound; thus economic sustainability is

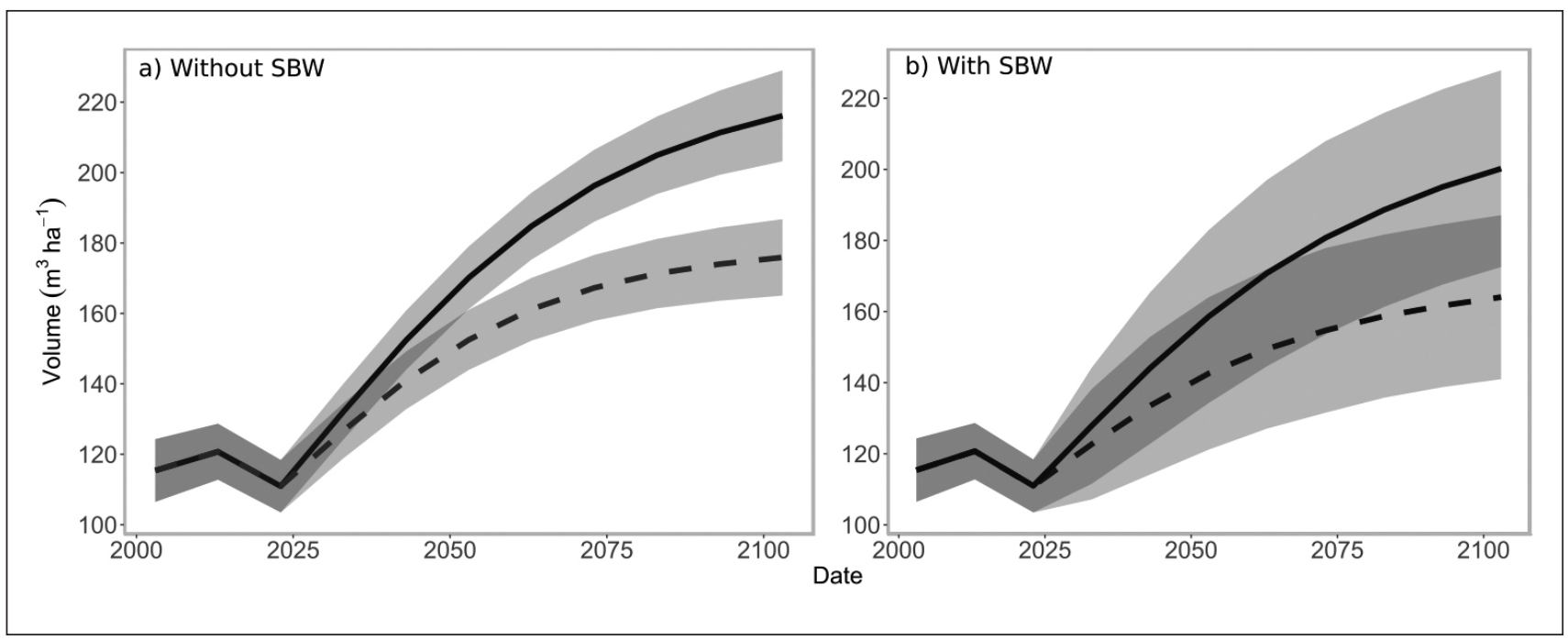

Fig. 4 Mean predicted volumes $\left(\mathrm{m}^{3} \cdot \mathrm{ha}^{-1}\right.$ ) and their 0.95 confidence interval for the Bas-Saint-Laurent region according to a $100-y e a r$ prediction. The confidence intervals rely on the assumption of a normal distribution. In (a), the solid line represents a growth scenario without disturbances, whereas the dashed line represents a scenario including only harvest. In (b), the solid line represents the scenario accounting for only SBW outbreaks, and the dashed line represents the scenario, including both SBW and harvesting (modified from Melo et al. 2019). 
favoured over ecological sustainability. As there is a large amount of uncertainty in the predictions, however, a reduction or increase in AAC may not differ from the business-asusual scenario. In other words, the precision of the modelling tools, which decreases as the simulation period increases, is not sufficiently high to effectively compare two scenarios using AACs. Moreover, the sampling design is not even considered.

Decision-makers and managers face an important challenge: they must act in the face of an uncertain future, often without the tools for estimating the extent of these uncertainties. The existing models used in AAC calculations, which guide forest planning, are not suitable to handle these uncertainties, especially those related to natural disturbances. Not only do the sampling design and model development need to be improved, but it is equally important to consider approaches that integrate the uncertainties of the estimated quantities at each growth step. Multiple studies present promising strategies to address the aforementioned issues (e.g., Eyvindson and Kangas 2016; Daniel et al. 2017; Álvarez-Miranda et al. 2019). These strategies range from analyzing the optimal plan concerning risk preferences to incorporating historical patterns of natural disturbance variability and addressing economic and sustainable criteria in the models. The common ground among these studies is the use of a stochastic approach, which can be better applied to the reality of growth models available in Quebec. Additionally, the uncertainties presented in Melo et al. (2019) show that relying on uncertain predictions to determine the longterm AAC calculations may not be as sustainable as would be expected. Potential strategies must promote discussion about short-term actions in forest management; deep uncertainty analysis recommends having flexible options and safety boundaries (Hallegatte 2009; Dittrich et al. 2016).

\section{Looking forward}

Silvicultural objectives are based on structural, compositional, yield, societal, and product/economic goals. Most objectives are relatively straightforward. Nonetheless, defining the structure of a forest stand (and its complexity) is challenging even when expert ratings are used (Frey et al. 2019). This forest stand definition has, until recently, relied on inventory data, e.g., diameter or height distributions ( $\mathrm{McEl}-$ hinny et al. 2005), or more elaborate measures of point processes (Pommerening 2002). Recent developments in remote sensing have enabled researchers to propose innovative, easy-to-obtain three-dimensional metrics to evaluate structural complexity (Seidel et al. 2015; Ehbrecht et al. 2016; Juchheim et al. 2017). Remote sensing has also captured forest dynamics (Martin-Ducup et al. 2017), underlining the important contribution of the rearrangement of a tree's branching architecture in filling gaps within a stand. These tools, such as a terrestrial laser scanner for local use (MartinDucup et al. 2018) or an aerial laser scanner (Bakx et al. 2019), can quantify stand structure. This information, which is becoming more accessible but is not yet used, can thus assess the structure of undisturbed stands and evaluate how they differ from managed ones.

Furthermore, forest managers now face a large challenge as the effects of global change begin to be observed in Cana- dian forests. The frequency and intensity of natural disturbances such as fires (Boulanger et al. 2017) and SBW outbreaks (Pureswaran et al. 2019) will increase with shifts in temperature and precipitation. Global change will also influence tree growth (D'Orangeville et al. 2018), regeneration (Splawinski et al. 2018), and drought-induced mortality (Hember et al. 2017). Changing pest and pathogen dynamics, whether from range expansions, such as that observed for mountain pine beetle in western Canada (Rosenberger et al. 2017), or from pests introduced from outside Canada (e.g., the emerald ash borer (Agrilus planipennis) described in Tanis and McCullough (2012) and the Asian long-horned beetle (Anoplophora glabripennis) discussed in Javal et al. (2019) greatly influence future scenarios. Forest dynamics will thus be greatly altered. The objective of the Quebec Ministry of Forests, Wildlife and Parks, which uses presettlement forests as a restoration objective for ecosystem-based forest management, has thus been questioned within the context of climate change. Will managing toward the benchmarks of past forest structure and composition ensure future forest ecosystem services and resiliency when climate and pest dynamics are altered? Boulanger et al. (2019) proposed that ecosystem functions, rather than composition or structure, should serve as EBM targets, at least in eastern Quebec. Their simulation results indicate that climate change will accelerate the already observed expansion-owing to harvesting over the last century- of temperate species, e.g., red and sugar maple, at the expense of boreal species, e.g., balsam fir and white spruce. Boulanger et al. (2019) found EBM to be the most promising approach for minimizing the differences with presettlement landscapes. Therefore, a focus on maintaining or restoring forest functions should be central to any forest management strategy. A caveat of such a strategy is, however, the difficulty for a regulator to quantify functional versus compositional and structural targets.

The forestry sector has also been called upon to mitigate greenhouse gas emissions through carbon sequestration (Dymond et al. 2016) and fossil fuel substitution (Laganière et al. 2017). The latter means of mitigation resides in societal choices and through government incentives, such as regulations and carbon taxes, whereas the former can be influenced by both silvicultural and management decisions. It is now well established that functionally diverse stands have higher productivity (Paquette and Messier 2011) and offer more functions (Forrester and Pretzsch 2015). Multi-aged stands, obtained from irregular shelterwood or uneven-aged systems, do not necessarily maximize carbon sequestration, but they spread carbon sequestration among various species and different-aged trees (D'Amato et al. 2011). Such complex stands are also more likely to be resistant and resilient to disturbance (O'Hara and Ramage 2013), thereby minimizing the risk of disturbances interrupting stand functions of sequestering carbon, providing habitat, and producing timber.

In recent years, there have been arguments for adopting a complex adaptive systems (CAS) approach to forest management (Puettmann and Messier 2020). The premise of CAS is that managers must act quickly to reduce the risks associated with uncertainty. Moreover, functional diversity is to be favoured through the grouping of species by functional traits and ensuring that trait redundancy at different scales, e.g., 
stand, management unit, and landscape, is maintained when making management decisions (Messier et al. 2019). The assumption is that redundancy will strengthen resilience to disturbance, be it natural, anthropogenic, or climatic. This approach is an appealing option for the mixed forests of eastern Quebec; applying CAS is more challenging in the boreal forest where tree diversity is lower. Although CAS theory may be more consistent with certain modern challenges in forest management, such as the influence of global market drivers on forest management or novel interactions among pathogens and trees (Messier et al. 2015), there are currently few examples of CAS being taken up by industry or government as a guiding paradigm. It thus remains an open question as to whether EBM, with some inconsistencies, will continue to prevail as the guiding philosophy for forest management.

The question is thus: What strategy best meets all the social, ecological, and economic goals expected from forest management? Although EBM and CAS are often discussed separately, they share several commonalities, especially where management decisions focus on maintaining or restoring forest functions. We have already underlined that forest management in eastern Quebec relies on even-aged systems, although these stands are found at a greater proportion relative to that produced within historical disturbance levels (Kneeshaw et al. 2008), and these practices have profoundly changed the forest landscape. The increased use of VRH and the adapting of this practice to reduce windthrow losses in the initial years post-harvest is a good start. Conversions of even-aged stands to uneven-aged/irregular stands must be increased to expand the presence of multi-aged stands across the landscape. Nevertheless, other alternatives, such as expanding-gap patterns, also must be considered to decrease the use of even-aged systems. Furthermore, species diversity should become an inherent silvicultural objective. Applying such management decisions will thus increase the proportion of complex stands in eastern Quebec, and the differences between presettlement and managed forest functions should be reduced. Finally, and most importantly, these decisions should not be constrained by AAC, as the uncertainty of the outcome is too high to compare scenarios.

\section{Acknowledgements}

The authors thank Mélanie Desrochers of the Centre d'étude de la forêt-Centre for Forest Research for the study sites map. The authors also thank the Quebec Ministère des forêts, de la faune et des parcs, the Natural Sciences and Engineering Research Council of Canada, and the Quebec Fonds de recherche - Nature et technologies for the financial support for the various projects described in the paper.

\section{References}

Aubin, I., C. Messier and A. Bouchard. 2008. Can plantations develop understory biological and physical attributes of naturally regenerated forests? Biol. Conserv. 141(10): 2461-2476. doi:10.1016/ j.biocon.2008.07.007

Álvarez-Miranda, E., J. Garcia-Gonzalo, C. Pais and A. Weintraub. 2019. A multicriteria stochastic optimization framework for sustainable forest decision making under uncertainty. For. Policy Econ. 103: 112-122. doi:10.1016/j.forpol.2018.03.006.
Baar, F., B. Snoeck, P. Balleux and H. Claessens. 2004. La sylviculture d'arbres" objectif" ou d'arbres de place (cahier technique ${ }^{\circ} 27$ ). For. Wallonne (68):2-8.

Bakx, T.R.M., Z. Koma, A.C. Seijmonsbergen and W.D. Kissling. 2019. Use and categorization of Light Detection and Ranging vegetation metrics in avian diversity and species distribution research. Divers. Distrib. 25(7): 1045-1059. doi:10.1111/ddi.12915.

Barrette, M., M. Leblanc, N. Thiffault, A. Paquette, L. Lavoie, L. Bélanger, F. Côté, J. Lamoureux et al. 2014. Issues and solutions for intensive plantation silviculture in a context of ecosystem management. For. Chron. 90(6): 748-762. doi:10.5558/tfc2014-147

Bastien, Y. 2005. Arbres objectifs et élagage artificiel. ENGREF Cent. Sylvic. Nancy Fr.: 23. Bédard, S., L. Bégin, L. De Grandpré, P. Duchesne, P. Grondin, J-P. Jetté, R. Jobidon, J-M. Lussier, D. Pothier, G. Prégent and J-C. Ruel 2003. Éclaircie commerciale pour le groupe de production prioritaire SEPM - Avis scientifique Comité consultatif scientifique du Manuel d'aménagement forestier. Ministère Ressour. Nat. Qué. Dir. Rech. For. 80 p.

Bergeron, Y. and B. Harvey. 1997. Basing silviculture on natural ecosystem dynamics: An approach applied to the southern boreal mixedwood forest of Quebec. For. Ecol. Manag. 92(1-3): 235-242. doi:10.1016/S0378-1127(96)03924-2.

Bergeron, Y., B. Harvey, A. Leduc and S. Gauthier. 1999. Forest management guidelines based on natural disturbance dynamics: stand- and forest-level considerations. For. Chron. 75(1): 49-54. NRC Research Press Ottawa, Canada.

Bergeron, Y., A. Leduc, B.D. Harvey and S. Gauthier. 2002. Natural fire regime: A guide for sustainable management of the Canadian boreal forest. Silva Fenn. 36(1): 81-95.

Bergès, L., M. Gosselin, F. Gosselin, Y. Dumas and $O$. Laroussinie. 2002. Prise en compte de la biodiversité dans la gestion forestière: éléments de méthode. Ingénieries-EAT N Spéc.: 45-55.

Blais, R. and J.L. Boucher. 2008. Les régimes forestiers québécois. Régimes d'accumulation, structures d'acteurs et modèles de développement (Centre de recherche sur les innovations sociales ed. Vol. cahier no ET0836): Centre de recherche sur les innovations sociales (CRISES)

Bouchard, M. and D. Pothier. 2010. Spatiotemporal variability in tree and stand mortality caused by spruce budworm outbreaks in eastern Quebec. Can. J. For. Res. 40(1): 86-94.

Boucher, Y., D. Arseneault and L. Sirois. 2006. Logging-induced change (1930-2002) of a preindustrial landscape at the northern range limit of northern hardwoods, eastern Canada. Can. J. For. Res. 36(2): 505- 517. doi:10.1139/x05-252.

Boucher, Y., D. Arseneault and L. Sirois 2009a. La forêt préindustrielle du Bas-Saint-Laurent et sa transformation (1820-2000): implications pour l'aménagement écosystémique. Le naturaliste Canadien 133(2): 60-69.

Boucher, Y., D. Arseneault, L. Sirois and L. Blais. 2009b. Logging pattern and landscape changes over the last century at the boreal and deciduous forest transition in Eastern Canada. Landsc. Ecol. 24(2): 171- 184. doi:10.1007/s10980-008-9294-8.

Boulanger, Y. and D. Arseneault. 2004. Spruce budworm outbreaks in eastern Quebec over the last 450 years. Can. J. For. Res. 34(5): 1035-1043. doi:10.1139/x03-269.

Boulanger, Y., D. Arseneault, Y. Boucher, S. Gauthier, D. Cyr, A.R. Taylor, D.T. Price and S. Dupuis. 2019. Climate change will affect the ability of forest management to reduce gaps between current and presettlement forest composition in southeastern Canada. Landsc. Ecol. 34(1): 159-174. doi:10.1007/s10980-018-0761-6.

Boulanger, Y., A.R. Taylor, D.T. Price, D. Cyr, E. McGarrigle, W. Rammer, G. Sainte-Marie, A. Beaudoin, L. Guindon and N. Mansuy. 2017. Climate change impacts on forest landscapes along the Canadian southern boreal forest transition zone. Landsc. Ecol. 32(7): 1415-1431. 
Cameron, A.D. 2002. Importance of early selective thinning in the development of long-term stand stability and improved log quality: a review. Forestry 75(1): 25-35.

Carter, D.R., R.S. Seymour, S. Fraver and A. Weiskittel. 2017. Reserve tree mortality in two expanding-gap silvicultural systems 20 years after establishment in the Acadian forest of Maine, USA. For. Ecol. Manag. 389: 149-157.

Chiasson, G. and É. Leclerc. 2013. La gouvernance locale des forêts publiques québécoises. Une avenue de développement des régions périphériques. Montréal, Presses de l’Université du Québec.

Condés, S. and R.E. McRoberts. 2017. Updating national forest inventory estimates of growing stock volume using hybrid inference. For. Ecol. Manag. 400: 48-57. doi:10.1016/j.foreco.2017.04.046.

Corona, P., L. Fattorini, S. Franceschi, G. Scrinzi and C. Torresan. 2014. Estimation of standing wood volume in forest compartments by exploiting airborne laser scanning information: Modelbased, design-based, and hybrid perspectives. Can. J. For. Res. 44(11): 1303-1311. NRC Research Press. doi:10.1139/cjfr-20140203 .

D'Amato, A.W., S.J. Troumbly, M.R. Saunders, K.J. Puettmann and M.A. Albers. 2011. Growth and survival of Picea glauca following thinning of plantations affected by eastern spruce budworm. North. J. Appl. For. 28(2): 72-78.

Daniel, C.J., M.T. Ter-Mikaelian, B.M. Wotton, B. Rayfield and M.-J. Fortin. 2017. Incorporating uncertainty into forest management planning: Timber harvest, wildfire and climate change in the boreal forest. For. Ecol. Manag. 400: 542-554. doi:10.1016/j.foreco. 2017.06.039.

Danneyrolles, V., S. Dupuis, D. Arseneault, R. Terrail, M. Leroyer, A. de Römer, G. Fortin, Y. Boucher and J.-C. Ruel. 2017. Eastern white cedar long-term dynamics in eastern Canada: Implications for restoration in the context of ecosystem-based management. For. Ecol. Manag. 400(Supplement C): 502-510. doi:10.1016/ j.foreco.2017.06.024.

Danneyrolles, V., S. Dupuis, G. Fortin, M. Leroyer, M., A. Römer, R. Terrail, M. Vellend, Y. Boucher, J. Laflamme, Y. Bergeron and D. Arseneault. 2019. Stronger influence of anthropogenic disturbance than climate change on century-scale compositional changes in northern forests. Nat. Commun. 10(1): 1265. doi:10.1038/s41467019-09265-z.

De Grandpré, L., D. Boucher, Y. Bergeron and D. Gagnon. 2011. Effects of small canopy gaps on boreal mixedwood understory vegetation dynamics. Community Ecol. 12(1): 67-77.

De Grandpré, L., K. Waldron, M. Bouchard, S. Gauthier, M. Beaudet, J.-C. Ruel, C. Hébert and

D.D. Kneeshaw. 2018. Incorporating insect and wind disturbances in a natural disturbance-based management framework for the boreal forest. Forests 9(8): 471.

De Potter, B., J. Perin, Q. Ponette and H. Claessens. 2012. Détourage d'arbres-objectif: enseignements des dispositifs installés en Wallonie après six années. For. Wallonne: 43-54.

Dittrich, R., A. Wreford and D. Moran. 2016. A survey of decision-making approaches for climate change adaptation: Are robust methods the way forward? Ecol. Econ. 122: 79-89. doi:10.1016/ j.ecolecon.2015.12.006.

D'Orangeville, L., D. Houle, L. Duchesne, R.P. Phillips, Y. Bergeron and D. Kneeshaw. 2018. Beneficial effects of climate warming on boreal tree growth may be transitory. Nat. Commun. 9(1): 1-10. Nature Publishing Group.

Dupont-Leduc, L., R. Schneider and L. Sirois. 2020. Preliminary results from a structural conversion thinning trial in Eastern Canada. J. For. 118(5): 515-533. doi:10.1093/jofore/fvaa022.

Dupuis, S., D. Arseneault and L. Sirois. 2011. Change from presettlement to present-day forest composition reconstructed from early land survey records in eastern Québec, Canada. J. Veg. Sci. 22(3): 564-575.
Dymond, C.C., S. Beukema, C.R. Nitschke, K.D. Coates and R.M. Scheller. 2016. Carbon sequestration in managed temperate coniferous forests under climate change. Biogeosciences. 13:1933- 1947. doi:10.5194/bg-13-1933-2016

Ehbrecht, M., P. Schall, J. Juchheim, C. Ammer and D. Seidel. 2016. Effective number of layers: A new measure for quantifying three-dimensional stand structure based on sampling with terrestrial LiDAR. For. Ecol. Manag. 380: 212-223. doi:10.1016/ j.foreco.2016.09.003.

Etheridge, D.A., MacLean, D.A., Wagner, R.G., and Wilson, J.S. 2005. Changes in landscape composition and stand structure from 1945-2002 on an industrial forest in New Brunswick, Canada. Can. J. For. Res. 35(8): 1965-1977. doi:10.1139/x05-110

Etheridge, D.A., D.A. MacLean, R.G. Wagner and J.S. Wilson. 2006. Effects of intensive forest management on stand and landscape characteristics in northern New Brunswick, Canada (1945-2027). Landscape Ecol. 21(4) 509-524. doi:10.1007/s10980005-2378-9

Eyvindson, K., and A. Kangas. 2016. Evaluating the required scenario set size for stochastic programming in forest management planning: Incorporating inventory and growth model uncertainty. Can. J. For. Res. 46(3): 340-347. doi:10.1139/cjfr-2014-0513.

Forrester, D.I. and H. Pretzsch. 2015. Tamm Review: On the strength of evidence when comparing ecosystem functions of mixtures with monocultures. For. Ecol. Manag. 356: 41-53.

Fortin, M. and L. Langevin. 2010. ARTÉMIS-2009 : un modèle de croissance basé sur une approche par tiges individuelles pour les forêts du Québec. Mémoire de recherche forestière no. 156. Ministère des Ressources naturelles et de la Faune, Direction de la recherche forestière.

Fortin, M., J. Bégin and L. Bélanger. 2003. Évolution de la structure diamétrale et de la composition des peuplements mixtes de sapin baumier et d'épinette rouge de la forêt primitive après une coupe à diamètre limite sur l'Aire d'observation de la rivière Ouareau. Can. J. For. Res. 33(4): 691-704

Franklin, J.F., D.F. Berg, D. Thornburg and J.C. Tappeiner. 1997. Alternative silvicultural approaches to timber harvesting: Variable retention harvest systems. Creating a forestry for the 21st century: the science of ecosystem management. Island Press, Washington, DC., 111-139.

Franklin, J.F., R.J. Mitchell and B.J. Palik. 2007. Natural disturbance and stand development principles for ecological forestry. United States Department of Agriculture, Forest Service. Available from http://www.treesearch.fs.fed.us/pubs/13293 [accessed 13 October 2016].

Franklin, J.F., T.A. Spies, R.V. Pelt, A.B. Carey, D.A. Thornburgh, D.R. Berg, D.B. Lindenmayer, M.E. Harmon, W.S. Keeton, D.C. Shaw, K. Bible and J. Chen. 2002. Disturbances and structural development of natural forest ecosystems with silvicultural implications, using Douglas-fir forests as an example. For. Ecol. Manag. 155(1-3): 399-423. doi:10.1016/S0378-1127(01) 00575-8.

Frey, J., B. Joa, U. Schraml and B. Koch. 2019. Same viewpoint different perspectives-a comparison of expert ratings with a TLS derived forest stand structural complexity index. Remote Sens. 11(9). doi:10.3390/rs11091137.

Gagné, L., L. Sirois and L. Lavoie. 2016. Comparaison du volume et de la valeur des bois résineux issus d'éclaircies par le bas et par dégagement d'arbres-élites dans l'Est du Canada. Can. J. For. Res. 46(11): 1320-1329.

Gagné, L., L. Sirois and L. Lavoie. 2019. Seed rain and seedling establishment of Picea glauca and

Abies balsamea after partial cutting in plantations and natural stands. Forests 10(3): 221. 
Gagnon, L., M. Perreault, M. Ruel, G. St-Hilaire, D. Raby and P. Sénéchal. 2018. Sommaire du plan d'aménagement forestier intégré tactique 2018-2023. Région du Bas-Saint-Laurent. Unité d'aménagement 012-72. Available from http://collections.banq.qc.ca/ark:/ 52327/3429802 [accessed 10 April 2020].

Gauthier, S. and M.-A.Vaillancourt. 2008. Aménagement écosystémique en forêt Boréale. Presses de l'Université du Québec.

Gauthray-Guyénet, V., R. Schneider, D. Paré, A. Achim, C. Loi and L. Sirois. 2018. Influence of shifts over an 80-year period in forest composition on soil properties. Plant Soil 433, 111-125.

Gauthray-Guyénet, V., R. Schneider, A. Achim, M. Fortin, D. Paré and D. Arseneault. In press. Legacy of forest composition and changes over the long-term on tree radial growth. Can. J. For. Res. Gouvernement du Québec. 2015. Loi sur l'aménagement durable du territoire forestier. Chapitre A-18.1. Éditeur officiel du Québec.

Grenon, F., J.-M. Lussier and L. Sirois. 2007. Conversion de jeunes forêts du Bas-St-Laurent en peuplements inéquiennes dans un contexte d'aménagement forestier écosystémique. UQAR Serv Can Cent Can Sur Fibre Bois: 80.

Groupe d'experts sur la sylviculture intensive de plantations. 2013. La sylviculture intensive de plantations dans un contexte d'aménagement écosystémique - Rapport du groupe d'experts sous la direction de M. Barrette et M. Leblanc. 120 p.

Guillemette, F., S. Bédard, D. Pin and D. Dumais. 2013. Les coupes de jardinage avec gestion par arbres. In: Le guide sylvicole du Québec, Les concepts et l'application de la sylviculture. Les Publications du Québec. pp. 567-604.

Gustafsson, L., J. Bauhus, T. Asbeck, A.L.D. Augustynczik, M. Basile, J. Frey, F. Gutzat, M. Hanewinkel, J. Helbach, M. Jonker, A. Knuff, C. Messier, J. Penner, P. Pyttel, A. Reif, F. Storch, N. Winiger, G. Winkel, R. Yousefpour and I. Storch. 2020. Retention as an integrated biodiversity conservation approach for continuouscover forestry in Europe. Ambio 49(1): 85-97. doi:10.1007/s13280019-01190-1.

Hallegatte, S. 2009. Strategies to adapt to an uncertain climate change. Glob. Environ. Change 19(2): 240-247. doi:10.1016/j.gloenvcha.2008.12.003.

Hansen, A.J., T.A. Spies, F.J. Swanson and J.L. Ohmann. 1991. Conserving biodiversity in managed forests. BioScience 41(6): 382 392.

Harvey, B.D., A. Leduc, S. Gauthier and Y. Bergeron. 2002. Standlandscape integration in natural disturbance-based management of the southern boreal forest. For. Ecol. Manag. 155(1): 369-385. doi:10.1016/S0378-1127(01)00573-4.

Hember, R.A., W.A. Kurz and N.C. Coops. 2017. Relationships between individual-tree mortality and water-balance variables indicate positive trends in water stress-induced tree mortality across North America. Glob. Change Biol. 23(4): 1691-1710. doi:10.1111/ gcb.13428.

Javal, M., E. Lombaert, T. Tsykun, C. Courtin, C. Kerdelhué, S. Prospero, A. Roques and G. Roux. 2019. Deciphering the worldwide invasion of the Asian long-horned beetle: A recurrent invasion process from the native area together with a bridgehead effect. Mol. Ecol. 28(5): 951-967. doi:10.1111/mec.15030.

Juchheim, J., C. Ammer, P. Schall and D. Seidel. 2017. Canopy space filling rather than conventional measures of structural diversity explains productivity of beech stands. For. Ecol. Manag. 395: 19-26. doi:10.1016/j.foreco.2017.03.036.

Kangas, A.S. and J. Kangas. 2004. Probability, possibility and evidence: Approaches to consider risk and uncertainty in forestry decision analysis. For. Policy Econ. 6(2): 169-188. doi:10.1016/S13899341(02)00083-7.

Kneeshaw, D.D. and Y. Bergeron. 1998. Canopy gap characteristics and tree replacement in the southeastern boreal forest. Ecology 79(3): 783-794. doi:10.1890/0012- 9658(1998)079[0783:CGCATR] 2.0.CO;2.
Kneeshaw, D.D., E. Lauzon, A. De Römer, G. Reyes, J. Belle-Isle, J. Messier and S. Gauthier. 2008. Appliquer les connaissances sur les régimes de perturbations naturelles pour développer une foresterie qui s' inspire de la nature dans le sud de la péninsule gaspésienne. In: Aménagement forestier écosystémique en forêt. University of Quebec Press, Quebec. pp. 215-240.

Laflèche, V., C. Larouche and F. Guillemette. 2013. L'éclaircie commerciale. In: Le guide sylvicole du Québec, Les concepts et l'application de la sylviculture. Les Publications du Québec. pp. 300-327. Laganière, J., D. Paré, E. Thiffault and P.Y. Bernier. 2017. Range and uncertainties in estimating delays in greenhouse gas mitigation potential of forest bioenergy sourced from Canadian forests. GCB Bioenergy 9(2): 358-369. doi:10.1111/gcbb.12327.

Lambert, M.-C., J. Rainville and M. Fortin. 2007. Expérimentation de détourage d'arbres objectifs situés dans des peuplements dégradés issus de CDL ayant subi une CMCD récente. Coopérative Forestière des Hautes-Laurentides. Available from http://notreforet.com/files/file/Exp\%C3\%A9rimentions\%20de\%20d\%C3\%A9 tourage\%20au\%20bleuets.p df [accessed 14 March 2017].

Lorimer, C.G. and A.S. White. 2003. Scale and frequency of natural disturbances in the northeastern US: Implications for early successional forest habitats and regional age distributions. For. Ecol. Manag. 185(1-2): 41-64.

Lundqvist, L., D. Chrimes, B. Elfving, T. Mörling and E. Valinger. 2007. Stand development after different thinnings in two unevenaged Picea abies forests in Sweden. For. Ecol. Manag. 238(1): 141-146. MacKinnon, W.E. and D.A. MacLean. 2004. Effects of surrounding forest and site conditions on growth reduction of balsam fir and spruce caused by spruce budworm defoliation. Can. J. For. Res. 34(11): 2351-2362.

MacLean, D.A. 1980. Vulnerability of fir-spruce stands during uncontrolled spruce budworm outbreaks: A review and discussion. For. Chron. 56(5): 213-221.

Martin, M., H. Morin and N.J. Fenton. 2019. Secondary disturbances of low and moderate severity drive the dynamics of eastern Canadian boreal old-growth forests. Ann. For. Sci. 76(4): 108. doi:10.1007/s13595-019-0891-2.

Martin-Ducup, O., R. Schneider and R.A. Fournier. 2017. A method to quantify canopy changes using multi-temporal terrestrial lidar data: Tree response to surrounding gaps. Agric. For. Meteorol. 237-238(Supplement C): 184-195. doi:10.1016/j.agrformet.2017. 02.016 .

Martin-Ducup, O., R. Schneider and R. Fournier. 2018. Analyzing the vertical distribution of crown material in mixed stand composed of two temperate tree species. Forests 9(11): 673

McElhinny, C., P. Gibbons, C. Brack and J. Bauhus. 2005. Forest and woodland stand structural complexity: Its definition and measurement. For. Ecol. Manag. 218(1-3): 1-24.

McRoberts, R.E., Q. Chen, G.M. Domke, G. Ståhl, S. Saarela and J.A. Westfall. 2016. Hybrid estimators for mean aboveground carbon per unit area. For. Ecol. Manag. 378: 44-56. doi:10.1016/ j.foreco.2016.07.007.

Melo, L.C., R. Schneider and M. Fortin. 2018. Estimating modeland sampling-related uncertainty in large-area growth predictions. Ecol. Model. 390: 62-69. doi:10.1016/j.ecolmodel.2018.10.011.

Melo, L.C., R. Schneider and M. Fortin. 2019. The effect of natural and anthropogenic disturbances on the uncertainty of large-area forest growth forecasts. For. Int. J. For. Res. 92(3): 231-241. doi:10.1093/forestry/cpz020.

Messier, C., J. Bauhus, F. Doyon, F. Maure, R. Sousa-Silva, P. Nolet, M. Mina, N. Aquilué, M.-J. Fortin and K. Puettmann. 2019. The functional complex network approach to foster forest resilience to global changes. For. Ecosyst. 6(1): 21. doi:10.1186/ s40663-019-0166-2. 
Messier, C., K. Puettmann, R. Chazdon, K.P. Andersson, V.A. Angers, L. Brotons, E. Filotas, R. Tittler, L. Parrott and S.A. Levin. 2015. From management to stewardship: Viewing forests as complex adaptive systems in an uncertain world. Conserv. Lett. 8(5): 368-377.

Ministère des Forêts, de la Faune et des Parcs. 2017a. L'intégration des enjeux écologiques dans les plans d'aménagement forestier intégré de 2018-2023. Cahier 1: Concepts généraux liés à l'aménagement écosystémique des forêts. Gouvernement du Québec. Direction de l'aménagement et de l'environnement For.: 30 p.

Ministère des Forêts, de la Faune et des Parcs 2017b. Insectes, maladies et feux dans les forêts du Québec. Direction de la protection des forêts contre les maladies. Gouvernement du Québec. Rapport no. 64 .

Ministère des Forêts, de la Faune et des Parcs. 2018. Détermination des possibilités forestières 2018- 2023. Synthèse régionale du Bas-Saint-Laurent. Ministère des Forêts, de la Faune et des Parcs, Gouvernement du Québec.

Mitchell, S.J. and W.J. Beese. 2002. The retention system: reconciling variable retention with the principles of silvicultural systems. For. Chron. 78(3): 397-403.

Mori, A.S., and R. Kitagawa. 2014. Retention forestry as a major paradigm for safeguarding forest biodiversity in productive landscapes: A global meta-analysis. Biol. Conserv. 175: 65-73. doi:10.1016/j.biocon.2014.04.016.

Nyland, R.D. 2002. Silviculture: Concepts and applications. In: 2nd edition. McGraw-Hill New York, New York, NY. Available from http://orton.catie.ac.cr/cgi- bin/wxis.exe/?IsisScript=SIBE01.xis\& method $=$ post\&formato $=2 \&$ cantidad $=1 \&$ expresion $=m f n=024014$ [accessed 17 December 2012].

Nyland, R.D. 2003. Even-to uneven-aged: The challenges of conversion. For. Ecol. Manag. 172(2-3): 291-300.

O'Hara, K.L. 2002. The historical development of uneven-aged silviculture in North America. Forestry 75(4): 339-346.

O'Hara, K.L. and B.S. Ramage. 2013. Silviculture in an uncertain world: Utilizing multi-aged management systems to integrate disturbance. Forestry 86(4): 401-410.

Paquette, A. and C. Messier. 2011. The effect of biodiversity on tree productivity: From temperate to boreal forests. Glob. Ecol. Biogeogr. 20(1): 170-180. doi:10.1111/j.1466-8238.2010.00592.x.

Pommerening, A. 2002. Approaches to quantifying forest structures. Forestry 75(3): 305-324. doi:10.1093/forestry/75.3.305.

Pothier, D. and I. Auger. 2011. NATURA-2009 : un modèle de prévision de la croissance à l'échelle du peuplement pour les forêts du Québec. Ministère des Ressources naturelles et de la Faune, Direction de la recherche forestière.

Pretzsch, H., M. Heym, S. Pinna and R. Schneider. 2014. Effect of variable retention cutting on the relationship between growth of coarse roots and stem of Picea mariana. Scand. J. For. Res. 0(0): 112. doi:10.1080/02827581.2014.903992.

Puettmann, K.J. and C. Messier. 2020. Simple guidelines to prepare forests for global change: The dog and the frisbee. Northwest Sci. 93(3-4): 209-225. Northwest Scientific Association. doi:10.3955/046.093.0305.

Pureswaran, D.S., M. Neau, M. Marchand, L. De Grandpré and D. Kneeshaw. 2019. Phenological synchrony between eastern spruce budworm and its host trees increases with warmer temperatures in the boreal forest. Ecol. Evol. 9(1): 576-586.

Raulier, F., A. Leduc and M.-A. Vaillantcourt. 2009. Aménagement de la forêt. In Manuel de foresterie. Nouvelle édition., Éditions Multimondes. Ordre des ingénieurs forestiers du Québec, Québec, Qc. 1510 p.

Raymond, P. and S. Bédard. 2017. The irregular shelterwood system as an alternative to clearcutting to achieve compositional and structural objectives in temperate mixedwood stands. For. Ecol. Manag. 398: 91-100. doi:10.1016/j.foreco.2017.04.042
Raymond, P., M. Prévost and V. Roy. 2020. Silvicultural options for rehabilitating high-graded mixedwood stands in northeastern North America. For. Ecol. Manag. 466: 118137. doi:10.1016/ j.foreco.2020.118137.

Rémillard, U. and R. Schneider. 2015. Multi-temporal analysis of the retention-trees groups structure using terrestrial laser scanner. La Grande Motte, France. pp. 168-170. Available from https://silvilaser2015.teledetection.fr/files/Proceedings_Silvilaser_22_09_2015_ 2.pdf.

Rheault, H. 2013. Gestion de l'incertitude. Gouvernement du Québec. Available from https://forestierenchef.gouv.qc.ca/wp-content/uploads/2013/01/023-27_MDPF_Incertitude.pdf.

Rosenberger, D.W., Venette, R.C., Maddox, M.P., and Aukema, B.H. 2017. Colonization behaviors of mountain pine beetle on novel hosts: implications for range expansion into northeastern North America. PloS One 12(5): e0176269.

Ruel, J.-C., S.J. Mitchell and M. Dornier. 2002. A GIS based approach to map wind exposure for windthrow hazard rating. North. J. Appl. For. 19(4): 183-187.

Schneider, R., T. Franceschini, E. Duchateau, A. BérubéDeschênes, L. Dupont-Leduc, S. Proudfoot, H. Power and F. de Coligny. 2021. Influencing plantation stand structure through close-to- nature silviculture. Eur. J. For. Res. doi:10.1007/s10342020-01349-6.

Schütz, J.-P. 1997. Sylviculture 2-La gestion des forêts irrégulières et mélangées. Presses polytechniques et universitaires romandes.

Schütz, J.P. 2001. Opportunities and strategies of transforming regular forests to irregular forests. For. Ecol. Manag. 151(1): 87-94.

Schütz, J.P. 2002. Silvicultural tools to develop irregular and diverse forest structures. Forestry 75(4): 329-337.

Seidel, D., C. Ammer and K. Puettmann. 2015. Describing forest canopy gaps efficiently, accurately, and objectively: New prospects through the use of terrestrial laser scanning. Agric. For. Meteorol. 213: 23-32.

Seymour, R.S., J. Guldin, D. Marshall and B. Palik. 2006. Largescale, long-term silvicultural experiments in the United States: Historical overview and contemporary examples. Allg. Forst Jagdztg. 177: 104-112.

Shannon, C.E. 1948. A mathematical theory of communication. Bell Syst. Tech. J. 27(3): 379-423.

Singer, M.T. and C.G. Lorimer. 1997. Crown release as a potential old-growth restoration approach in northern hardwoods. Can. J. For. Res. 27(8): 1222-1232.

Splawinski, T.B., D. Cyr, S. Gauthier, J.-P. Jetté and Y. Bergeron. 2018. Analyzing risk of regeneration failure in the managed boreal forest of northwestern Quebec. Can. J. For. Res. 49(6): 680- 691. NRC Research Press. doi:10.1139/cjfr-2018-0278.

Ståhl, G., S. Holm, T.G. Gregoire, T. Gobakken, E. Næsset and R. Nelson. 2010. Model-based inference for biomass estimation in a LiDAR sample survey in Hedmark County, Norway. Can. J. For. Res. 41(1): 96-107. doi:10.1139/X10-161.

Tanis, S.R. and D.G. McCullough. 2012. Differential persistence of blue ash and white ash following emerald ash borer invasion. Can. J. For. Res. 42(8): 1542-1550.

Thomas, J.W., C. Maser and J.E. Rodiek. 1979. Wildlife habitats in managed rangelands-the Great Basin of southeastern Oregon: Riparian zones. US Department of Agriculture, Forest Service, Pacific Northwest Research Station Research paper 80.

Walker, W.E., P. Harremoës, J. Rotmans, J.P. van der Sluijs, M.B.A. van Asselt, P. Janssen and M.P.K. von Krauss. 2003. Defining uncertainty: a conceptual basis for uncertainty management in model-based decision support. Integr. Assess. 4(1): 5-17. doi:10.1076/iaij.4.1.5.16466. 